\title{
Deoxyribonucleic Acid Reassociation Between Actinomyces denticolens and Other Actinomyces Species from Dental Plaque
}

\author{
V. E. DENT $\dagger$ AND R. A. D. WILLIAMS* \\ Department of Biochemistry, The London Hospital Medical College, London, E1 2AD, United Kingdom
}

\begin{abstract}
The status of the new species Actinomyces denticolens was established by deoxyribonucleic aciddeoxyribonucleic acid homology. The level of homology with Actinomyces naeslundii, Actinomyces viscosus, and Actinomyces howellii was low in each case.
\end{abstract}

Actinomyces denticolens has been proposed as a new taxon for strains which have been isolated from the dental plaque of cattle and which have physiological similarities to Actinomyces naeslundii but are different in electrophoretic polypeptide pattern and cell wall carbohydrate components. Deoxyribohucleic acid (DNA)-DNA homology confirms the distinction among $A$. denticolens, $A$. naeslundii, and Actinomyces howellii.

Among the predominant components of the bacterial flora of dental plaque from a wide range of mammals, Actinomyces isolates were found in virtually all of the individuals (3). The strains isolated were all presumptively identified as either Actinomyces viscosus or A. naeslundii on the basis of physiological properties (9). Among the putative strains of $A$. naeslundii, 35 isolates had sodium dodecyl sulfate-polyacrylamide gel electrophoresis patterns similar to those of culture collection strains of this species (Dent and Williams, unpublished data), but the isolates from dairy cattle had several distinct patterns of polypeptides. Strains which had only rhamnose as a cell wall carbohydrate, failed to ferment trehalose, and fermented mannose weakly were described as $A$. denticolens (4), and isolates which contained glucose and rhamnose in their cell walls and were less widely fermentative than $A$. naeslundii were allocated to another new species, $A$. howellii (5). In this paper we report the results of DNA-DNA homology studies with $A$. denticolens and representatives of other Actinomyces species with similar DNA mean base compositions and physiological properties.
The strains used and their sources are listed in Table 1. DNA was isolated and purified as described previously for A. howellii (5). The mean base composition was determined from the melting temperature in dilute saline citrate by using the following formula: guanine-plus-cytosine content $=50.9$ +2.08 (melting temperature of unknown - melting temperature of Escherichia coli strain B DNA) (7). DNA type VIII (catalog no. D2001; Sigma London Ltd.) was used as an internal standard. The guanine-plus-cytosine content of the DNA (65.9 to $67.7 \mathrm{~mol} \%$ ) was similar to the guanine-pluscytosine contents of DNAs of $A$. naeslundii (9), A. viscosus (2), and $A$. howellii (5), but distinct from the guanine-pluscytosine contents of DNAs of Actinomyces bovis, Actinomyces israelii, and Actinomyces odontolyticus (9).

For homology studies DNA was purified by cesium chloride density gradient centrifugation and labeled by nick translation with ${ }^{3} \mathrm{H}$-labeled deoxycytidine triphosphate (kit TRK 700; Amersham International), and homology determinations were carried out on $5-\mathrm{mm}$ nitrocellulose membrane disks $(1,10)$. Our results (Table 2) show that the strains described as $A$. denticolens (4) form a homology group which has low DNA-DNA homology with recent isolates of $A$. naeslundii from the dental plaque of primates (strains $\mathrm{BB} 1 / 1958$ and $\mathrm{SM} / 1643$ ) and with strain WVU 45, which is equivalent to the type strain of this species. Similar low levels of homology were observed between $A$. denticolens and the type strain of $A$. howellii and between $A$. denticolens and strain T6, which is equivalent to the type strain of $A$.

TABLE 1. Designations and sources of Actinomyces strains

\begin{tabular}{|c|c|c|}
\hline Strain & Origin & Source \\
\hline $\begin{array}{l}\text { A. denticolens } \\
\text { NCTC } 11490^{\mathrm{T}}\left(=\mathrm{Sh} 8 / 4303^{\mathrm{T}}\right)^{a} \\
\text { Sh8/4313 } \\
\text { Sh } 5 / 4040 \\
\text { Sh } 7 / 4277 \\
\text { Sh } 7 / 4250\end{array}$ & Dental plaque of dairy cattle & V. E. Dent, London Zoo \\
\hline $\begin{array}{l}\text { A. naeslundii } \\
\text { BB1 } 1958 \\
\text { SM } / 1643 \\
\text { WVU } 45^{\mathrm{T}}\left(=\text { ATCC } 12104^{\mathrm{T}}\right) \\
\text { A. viscosus T6 } \text { T }^{\mathrm{T}}\left(=\mathrm{ATCC} 15987^{\mathrm{T}}\right) \\
\text { A. howellii NCTC } 11636^{\mathrm{T}}\left(=\mathrm{Sh}^{\mathrm{N}} 7 / 4276^{\mathrm{T}}\right)\end{array}$ & $\begin{array}{l}\text { Dental plaque of bush baby } \\
\text { Dental plaque of spider monkey } \\
\text { Sinus after dental extraction } \\
\text { Hamster mouth } \\
\text { Dental plaque of dairy cattle }\end{array}$ & $\begin{array}{l}\text { V. E. Dent, London Zoo } \\
\text { V. E. Dent, London Zoo } \\
\text { G. H. Bowden, Winnepeg, Canada } \\
\text { G. H. Bowden, Winnepeg, Canada } \\
\text { V. E. Dent, London Zoo }\end{array}$ \\
\hline
\end{tabular}

${ }^{a} \mathrm{~T}=$ type strain.

* Corresponding author.

$\dagger$ Present address: Department of Botany, Queens University, Belfast, BT7 1NN, United Kingdom. viscosus. It is known that $A$. viscosus is heterogeneous serologically (6) and in DNA-DNA homology (2), although it has much in common with $A$. naeslundii physiologically (8). Despite this, it was not necessary to conduct hybridizations 
TABLE 2. DNA relatedness values among A. denticolens and other Actinomyces species

\begin{tabular}{|c|c|c|c|c|c|c|c|c|}
\hline \multirow[b]{2}{*}{ Strain } & \multirow{2}{*}{$\begin{array}{l}\text { Guanine-plus- } \\
\text { cytosine } \\
\text { content of } \\
\text { DNA (mol\%) }\end{array}$} & \multicolumn{7}{|c|}{ \% Relatedness to strain: } \\
\hline & & Sh $5 / 4040$ & $\operatorname{Sh} 7 / 4277$ & BB1/1958 & $\mathrm{SM} / 1643$ & WVU $45^{\mathrm{T}}$ & $\mathrm{T} 6^{\mathrm{T}}$ & $\operatorname{Sh} 7 / 4276^{\mathrm{T}}$ \\
\hline \multicolumn{9}{|l|}{ A. denticolens } \\
\hline NCTC $11490^{\mathrm{T}}\left(=\operatorname{Sh} 8 / 4303^{\mathrm{T}}\right)$ & 66.7 & 103 & 77 & 19 & 33 & 39 & 21 & 30 \\
\hline Sh $8 / 4313$ & 66.7 & 88 & 73 & 19 & 27 & 29 & 21 & 25 \\
\hline Sh $5 / 4040$ & 67.7 & 100 & 88 & 20 & 27 & 36 & 25 & 28 \\
\hline Sh $7 / 4277$ & 67.5 & 89 & 100 & 25 & 26 & 32 & 33 & 24 \\
\hline $\mathrm{Sh} 7 / 4250$ & 65.9 & 99 & 97 & 21 & 32 & 38 & 26 & 32 \\
\hline \multicolumn{9}{|l|}{ A. naeslundii } \\
\hline BB1/1958 & 65.9 & 20 & 21 & 100 & $\mathrm{NT}^{a}$ & 84 & 46 & NT \\
\hline $\mathrm{SM} / 1643$ & 64.8 & 29 & NT & NT & 100 & 99 & NT & 24 \\
\hline WVU $45^{\mathrm{T}}\left(=\right.$ ATCC $\left.12104^{\mathrm{T}}\right)$ & 64.0 & 26 & NT & NT & NT & 100 & NT & NT \\
\hline \multicolumn{9}{|l|}{ A. viscosus } \\
\hline T6 $^{\mathrm{T}}\left(=\right.$ ATCC $\left.15987^{\mathrm{T}}\right)$ & 66.1 & 28 & 26 & 46 & NT & 67 & 100 & 29 \\
\hline \multicolumn{9}{|l|}{ A. howellii } \\
\hline NCTC $11636^{\mathrm{T}}\left(=\operatorname{Sh} 7 / 4276^{\mathrm{T}}\right)$ & 66.7 & 34 & NT & NT & 31 & 20 & 20 & 100 \\
\hline \multicolumn{9}{|l|}{ Lactobacillus odontolyticus } \\
\hline NCTC 1407 & & 3 & 1 & 4 & 2 & 1 & 3 & 2 \\
\hline
\end{tabular}

${ }^{a}$ NT, Not tested.

with strains other than type strains, because $A$. denticolens is clearly distinguishable from both serotypes of $A$. viscosus and from both "typical" and "atypical" strains of $A$. naeslundii (6) by its unique and simple cell wall carbohydrate content and also its strikingly different electrophoretic pattern of polypeptides (4). Therefore, our data confirm the status of $A$. denticolens as a distinct new species.

This work was supported by project grants G979295SB and G8207598SB from the Medical Research Council.

\section{LITERATURE CITED}

1. Back, W., and E. Stackebrandt. 1978. DNS-DNS-HomologieStudien innerhalb der Gattung Pediococcus. Arch. Microbiol. 118:79-85.

2. Coykendall, A. L., and A. J. Munzenmaier. 1979. Deoxyribonucleic acid hybridization among strains of Actinomyces viscosus and Actinomyces naeslundii. Int. J. Syst. Bacteriol. 29:234-240.

3. Dent, V. E., and P. D. Marsh. 1981. Evidence for a basic plaque microbial community on the tooth surface in animals. Arch.
Oral Biol. 26:171-179.

4. Dent, V. E., and R. A. D. Williams. 1984. Actinomyces denticolens Dent \& Williams sp. nov.: a new species from the dental plaque of cattle. J. Appl. Bacteriol. 56:183-192.

5. Dent, V. E., and R. A. D. Williams. 1984. Actinomyces howellii, a new species from the dental plaque of dairy cattle. Int. J. Syst. Bacteriol. 34:316-320.

6. Fillery, E. D., G. H. Bowden, and J. M. Hardie. 1978. A comparison of strains of bacteria designated Actinomyces viscosus and Actinomyces naeslundii. Caries Res. 12:299-312.

7. Owen, R. J., and L. R. Hill. 1979. The estimation of base compositions, base pairing and genome sizes of bacterial deoxyribonucleic acids. Soc. Appl. Bacteriol. Tech. Ser. 14:277-296.

8. Schofield, G. M., and K. P. Schaal. 1981. A numerical taxonomic study of members of the Actinomycetaceae and related taxa. J. Gen. Microbiol. 127:237-259.

9. Slack, J. M., and M. A. Gerencser. 1975. Actinomyces, filamentous bacteria. Biology and pathogenicity. Burgess Publishing Co., Minneapolis.

10. Stackebrandt, E., and F. Fiedler. 1979. DNA-DNA homology studies among strains of Arthrobacter and Brevibacterium. Arch. Microbiol. 120:289-295. 